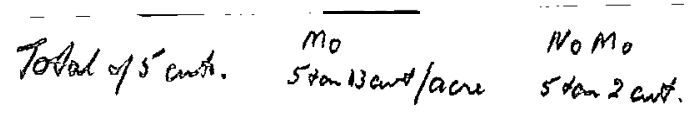

\title{
MOLYBDENUM AND LEGUMES
}

By A. F. R. ADAMS, Research Chemist, Canterbury Agricultural College; Lincoln.

\section{THE ROLE OF MOLYBDENUM}

In.1930 Bortels published a paper entitled "Molybdenum as a Catalyst in the Biological Fixation of Nitrogen." Using Azotobacter chroococcum, a freeliving nitrogen-fixing bacterium, he showed that if grown in a nitrogen-free nutrient solution, its growth was stimulated by the addition of a very small amount of sodium molybdate. In another paper in 1933 he reported 100 -fold increase in the fixation of nitrogen by this and other species of bacteria when supplied with molybdenum. Portels was thus the first to establish the biological importance of molybdenum.

In 1936 Steinberg showed that Aspergillus niger, a fungus, also needed traces of molybdenum for complete growth and also found that more was needed when supplied with nitrate nitrogen than when the nitrogen was given as an ammonium salt.

-Until this time it was thought that the only role of molybdenum was that of a specific catalyst in the process of nitrogen fixation, but Steinberg's work led him to suggest that it may also play a part in the reduction of nitrate.

Practically all the work on molybdenum up to 1936 had been done on bacteria or fungi, and indeed it was not until 1939 that Arnon and Stout established the essential nature of molybdenum for higher plants. However, in 1937 Bortels, growing peas,-soy beans, and red clover in sand cultures, obtained increases in nitrogen fixation and growth with small additions of molybdenum compounds, and this led him to suggest the possible importance of molybdenum in the symbiotic fixation of nitrogen by members of the legume family. Similar results were obtained in 1943 by Jensen and Betty with clovers and lucerne. They also -produced the same effect by the application of calcium carbonate, due of course to the increased uptake of the traces of molybdenum in the soil. 
These experiments and many others have conclusively shown that in the absence -of added nitrogen: molybdenum is required for the symbiotic fixation or nitrogen, in other words, it is needed to enable the rhizobium satisfactorily to perform its function of fixing atmospheric nitrogen. More recent work $b_{y}$ Hewitt and Jones (1948) and Evans has further definitely proved that molybdenum is needed in legumes for the reduction of nitrates, as they have successfully produced molybdenum-deficient legumes even when nitrate was supplied. However, because of the extremely small amounts of molybdenum needed for this process, very few, if any, workers have obtained responses under conditions of soil culture where nitrate has been supplied. This second role for molybdenum had been established much earlier in the work' on non$\mathrm{l}$ e g u m e s.

The position when' nitrogen in the ammonium form is added to legumes grown in soil has not yet been clarified, but again, most if not all work indicates that no increased benefit is obtained from the use of molybdenum.

It can be said that molybdenum plays a dual role in the nutrition of legumes,

1. It is needed to enable the symbiotic bacteria to perform their function of fixing atmospheric nitrogen.

2. It is needed in much smaller amount for the reduction of nitrate. The first of these is by far the most important factor in most molybdenum-responsive soils.

An interesting piece of work concerning legumes, though hardly within the scope of grasslands, was recently published by Meagher, Johnson, and Stout, (1952) who found that the seeds of peas and beans contain more than enough molybdenum to enable the growth of the plant to reach maturity. They claim that this is the only known example of a seed with this capability. This work explains the success, of Australian workers who in an area where beans suffer from molybdenum deficiency (bean scald) found that the trouble could be avoided by using bean seed grown in another district.

EXPERIMENTS WITH LUCERNE AT LINCOLN

The area on which the work to be 'described is

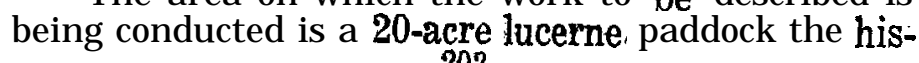
203 
tory of which is known since 1940. From 1940 to 1947 it was in lucerne and during that time received normal dressings of lime and superphosphate and was considered a better than average lucerne stand. In 1948 it was ploughed and sown to 'Cross 7 wheat and yielded 51 bushels ; the following 2 years it grew Algerian oats for chaff and greenfeed and after summer fallowing it was again sown to lucerne in February. 1951 after very thorough seed-bed preparation. A ! perfect strike resulted, but in the spring it was noticed that with the exception of one or two very small patches the plants over the whole paddock were a pale yellow-green, as if they were suffering from nitrogen deficiency. Not only this, but many of the young plants had died. The yield of material from the first cut substantiated the observation that the paddock was indeed a poor example of a young lucerne stand. It was decided to investigate possible causes of this, especially as many similar cases of failure where lucerne followed lucerne had previously come to our notice. Three possibilities were discussed:-

1. A nutrient deficiency.

2. A virus.

3. A toxic root excretion from the previous lucerne crop.

In this paper the work done under the first heading will be presented, and in so doing, I will digress somewhat from the main theme of molybdenum because I feel that the whole trial will be of interest. I should mention too, that the third possibility is. being investigated by another member of the Lincoln staff. Work. overseas with clover strongly indicates that the roots do exude a substance which is particularly toxic to young clover plants.

\section{DESIGN OF EXPERIMENT}

The following nutrients were looked upon as possible limiting factors-calcium, phosphorus, potassium, nitrogen, boron, and molybdenum. The whole area was treated with adequate lime and superphosphate, thus eliminating the first two from'the -above list.

The four remaining nutrients, at one level of each, were included in all combinations and all treatments replicated twice and randomised. The soil of this area is classified as Paparua sandy loam on sand-a recent to young soil-in the provisional Plains and 
Downlands map of the Soil Bureau. The $\mathrm{pH}$ ranged from 5.7 to 6.2. The treatments were applied in solution on 4th January, 1952 at the following rates:

$\begin{array}{llc}\text { Potassium } & \text { (K) as chloride } & \text { 2tcwt. per acre } \\ \text { Nitrogen } & \text { (N) as ammonium aulphate 2zcwt. " " } \\ \text { Boron } & \text { (B) as borax } & \text { 20lb. " " " } \\ \text { Molybdenum } & \text { (Mo) as amm. molybdate } & \text { 40z. " " " }\end{array}$

A few days after treatment leaf scorch was evident, especially on the plots receiving both $\mathrm{N}$ and $\mathrm{K}$, due to the solution being too concentrated. Most noticeable, however, was the very pronounced improvement in colour and vigour of the plots receiving molybdenum. The summarised data from the first cut, 8.2.52, and the second cut, 18.352, are shown in Table I.

\section{TABLE I..}

Yields of Herbage in lb. Dry Matter Per Acre and Percentages of Total Nitrogen

First Cut

(a) Total Herbage Yields.

$$
\begin{aligned}
& \text { Mean trial yield } \\
& \text { Main effect of molybdenum } \\
& \text { Main effect of potash } \\
& \text { Main effect of nitrogen } \\
& \text { Main effect of boron }
\end{aligned}
$$

lb. dry matter per acre 1700

$$
\begin{aligned}
& 1700 \\
& 4501 b . \text { (sig. } 1 \% \text { level) } \\
& -140 " \text { (sig. } 10 \% \text { level) } \\
& -60 \text { "(not sig.) } \\
& -120 " \text { (not sig.) }
\end{aligned}
$$

(b) Percentages of Total Nitrogen.

Mean of plots without molyb-

$$
\text { denum }
$$

$2.71 \%$

Main effect of molybdenum $\quad 0.7 \%$ (sig. 1\% level)

\section{Second Cut}

(a) Total Herbage Yields.

Mean trial yield
Main effect of molybdenum
Main effect of potash
Main effect of nitrogen
Main effect of boron

lb. dry matter per acre 685
170 (sig. $2 \%$ )
30 (not sig.)
50 ("," $)$ (",)

(b) Percentages of Total Nitrogen.

Mean of plots without molybdenum

'The highly beneficial effect of the molybdenum treatments is very evident from the above figures, both on .a. yield basis and on nutritive value. Leaf to stalk ratio, examined only on the first cut, was also significantly in favour of the molybdenum treatment. . 205 
This season the following additional treatments were applied in the dry state on 3rd September, 1952.

Potassium chloride at lcwt. per acre.

Ammonium sulphate at lcwt. per acre.

Molybdenum on one half the original molybdenum plots, which were split, at 20z. per acre in solution.

The results from the first cut on October 24, 1952, are-shown in Table II.

TABLE II.

Yields of Herbage in lb. Dry Matter per Acre and Percentages of Total Nitrogen.

(a) Total Herbage Yields lb. dry matter per acre

Mean 'trial yield 2215

Main effect of molybdenum $\quad 150$ (sig. 5\% level)

Main effect of potash $\quad-70$ (not sig.)

Main effect of nitrogen $\quad 190$ (sig. $1 \%$ level)

Main effect of boron 170 ( ; $2 \%$ level)

(b) Percentages of Total Nitrogen.

Mean of plots without molybdenum

Main effect of molybdenum

Mean of plots without nitro-

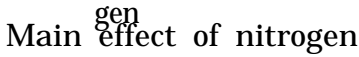

$3.48 \%$

$0.35 \%$ (sig. $1 \%$ level)

$3.70 \%$

$-0.09 \%$ (sig. $5 \%$ level)

No differences in yield were shown in the plots which received additional molybdenum this year. Points of interest are the responses to nitrogen, boron, and molybdenum and the lack of response to potassium, considering that probably $17001 \mathrm{~b}$. of $\mathrm{K}_{2} \mathrm{O}$ per acre has been removed from the paddock in the last 12 years. Whatever else is lacking in these soils it is apparent that the reserves of potassium are considerable.

Molybdenum contents in p.p.m. of the plant tops were :-First cut: treated 0.50, untreated 0.10; and in the second cut: treated 0.51 , untreated 0.15 . Two soil samples from the paddock, taken before the trial, gave 0.14 and 0.16 p.p.m. -of available molybdenum. The $\mathrm{pH}$ of the soil at present is 6.4.

\section{SUMMARY}

On second-crop lucerne molybdenum has significantly increased the yield and nitrogen content of the crop. This finding may assume some. importance-in view of the fact that second-crop failure is not un. common in Canterbury and that the area suitable for -206 . 
lucerne on many farms is limited. We feel that better results would be-obtained if molybdenum were applied at sowing and we intend to plough and resow with molybdenised superphosphate another area in the same paddock to investigate this aspect. More work is needed to determine the optimum dressing, which may well be found, as in Australia, to be of the order of 1oz. per acre, and to determine the time over which one dressing remains effective.

In Canterbury I consider that molybdenum will be found most useful in the development stages of better pasture establishment on the podzolic and pan soils of the downlands and on some of the older, more leached soils of the plains. It should also prove of "major benefit in the improvement of pastures in hill country where the inability to get lime on has been a limiting factor, as the use of molybdenised superphosphate should enable the satisfactory establishment of clovers. I am concerned about the tendency to regard molybdenum as the complete substitute for lime. The many desirable effects of lime, such as rendering phosphate more readily available, the promotion of suitable conditions for the encouragement of a desirable soil fauna, the provision of calcium-a major plant nutrient-and many others make it necessary for us to look on any such tendency with considerable caution. On the other. hand, with the exception of copper-deficient soils, provided that molybdenum is used with due care and preferably only after expert advice has been sought, I do not think that its use will have any detrimental effect on stock health.

\section{Acknowledgements :}

Thanks are due to Mr Iversen, who was largely instrumental in initiating this work, to $\mathrm{Mr} \mathrm{G}$. Wright of the Crop Research Division, D.S.I.R., for advice on the plot lay-out, and to various members of the Lincoln College staff for assistance in field work.

\section{REFERENCES}

Bortels, H. (1930) Chem. Abs. 26, 2481, 1932.

Bortels, H. (1,933) Chem. Abs. 27, 1972, 1933:

Steinberg, R. A. (1936) J. Agr. Res. 52, 439.

Steinberg, R. A. (1937) J. Agr. Res. 55, 891.

Arnon; D. I. \& Stout, P. R. (1939) Plant Phys. 14, 599. 207 
Bortels, H. (1937) Chem. Abs. 31, 6395, 1937.

Jensen, H. L. \& Betty,' R. G. (1943) Linn. Soc. N.S.W. Proc. 68. 1'

Hewitt, E J. \& Jones, E. W. (1948) Ann. Rept. Long Ashton. 81 .

Evans, H. J., Purvis, E. R. \& Bear F. E. (1950) Plant Phys. 25. 55.

Meagher, W. R., Johnson, C. M. \& Stout. P. R. (1952) Plant Phys. 27. 223.'

\section{I S C U S S I O N}

Q. How long will one dressing of molybdenum be effective?

A. (Davies) : Molybdenum research is quite a new thing and trials with molybdenum have not -continued long enough to give reliable, information with regard to this point. We have examined the soil from molybdenum plots at Invermay Research Station. Samples were taken of every layer of the top few inches of the soil. From the chemical analysis of these samples it appears that the applied molybdenum stays in the top few inches. The effect of molybdenum application may therefore be expected to last several years.

A. (Adams ): The second dressing of molybdenum on the Lincoln College trial with lucerne described in my pap'er gave no additional responses when compared with the plots which had received only an initial dressing of molyplots which had received only an initial dressing of moly-
bdenum. On the other hand there is some evidence frbm a farm in North Canterbury which shows that molybdenum is running out and that another dressing is desirable.

Q. Have you had an interaction between molybdenum and boron in the Lincoln trials?

A. (Adams) : No. The only interaction was between potash and boron. This was a positive interaction.

Q. Do you know anybody who has tried sowing seed with molybdenum and what were the results?

A. (Lobb) : Several methods of applying molybdenum were used in trials in North Otago. Good responses were obtained where grass and rape seed was dusted with molybdenum.

(P. Mitchell): As representative of Potash Limited I am interested to note that in spite of a considerable drain of potash from the field on which the Lincoln trial was situated, no responses to potash were obtained. In overseas trials it has been found that where light surface applications failed potash may still give responses when applied as heavy surface applications or below the surface.

(Adams) : Potash applied at the rate of $2 \frac{1}{2} \mathrm{cwt}$. per acre of muriate of potash is considered a heavy application in Canterbury. Most of the soils in Canterbury seem well supplied with potash and seem to be able to renew supplies of available potash. 
Q. Has there been considerable 'response. of grasses as well as of clovers after the application of, molybdenum?

A.: '(Davies): In one -or two trials farmers indicated greater grazing.. of grasses by stock; presumably this was preceded by a grass response.

(Lobb) : In North Otago we had good responses with oats and wheat; these plants belong to the same family as our pasture grasses

On Kauru silt loam grass failed to establish without molybdenum.

(Dr Melville) : I should like to ask two questions: With regard to the lime-molybdenum relation, what is a desirable level of liming on molybdenum-deficient soil ? Secondly, has nodulation been increased or decreased following the application of molybdenum to clovers?

A. (Davies): With regard to the lime requirements of molybdenum-deficient soils we have not much experimental evidence. We have held that normal applications of lime are essential.

Literature reports that on molybdenum-deficient clovers nodules if anything are more numerous, but are small and of brownish appearance. When the molybdenum deficiency is made up nodules increase in size and assume a pink colour.

In a rate of liming trial of mine I discovered that the soil was likely to be molybdenum deficient. After dressing the whole trial area with sodium molybdate all lime effects which could be observed before were swamped by the response of growth due to molybdenum. The control plots with $\mathrm{pH} 5$ and little available lime are now as good as the limed plots. It seems that on certain soils clovers will grow perfectly well at pH5 and little available lime.

Q. What are the harmful effects on stock?

A. (Dr J. F. Filmer) : I should like to issue a warning against the indiscriminate use of molybdenum We know that too much can cauae frouble. This is the case in England, where molybdenum is naturally present in some pastures at a high level. There is no evidence that the use of molybdenum 'will remedy any stock troubles which occur in New Z ealand. There is a complicated interaction between copper and molybdenum, but we do not know the whole story.

$M y$ advice is: Do not use molybdenum at all without obtaining advice from extension officers of the Department of Agriculture or from 'Agricultural Colleges. If you use it, on no account use more than the recommended amount.

C. J. Hamblyn: In my district the most outstanding response to molybdenum was on a hill-country pasture never topdressed or limed. The response was such that in our endeavours to improve hill-country swards I would say, go to it. It was a clover-deficient pasture oversown with clover seed at the beginning of the trial. The first response to molybdenum was purely a grass response. On molybdenum-deficient hill country I would tackle the problem by finding ways and means of applying molybdenum without phosphates and lime. 
G. A. Holmes: Our country in Invermay is very deficient in phosphate. Our responses to molybdenum without phosphate are negligible, but when phosphates are applied with molybdenum wonderful responses are obtained on browntop country.

W. R. Lobb: Most trials in North Otago are on paddocks which had little or no phosphates and have fairly low levels of phosphate as determined by chemical quick test. I am of the opinion that on the browntop country of North Otago improvement is possible with oversowing of clover seed and the application of molybdenum without initially applying phosphate. 